\title{
PROBLEMS OF PROVIDING AFFORDABLE HIGH QUALITY STUDENT HOUSING IN CONTEXT OF DEVELOPMENT OF MAJOR LATVIAN UNIVERSITIES
}

\author{
Sandra Gusta ${ }^{1}$, Inese Gusta ${ }^{2}$ \\ ${ }^{1}$ Latvia University of Life Sciences and Technologies, Latvia; ${ }^{2}$ Riga Technical University, Latvia \\ sandra.gusta@1lu.lv, gusta.inese@gmail.com
}

\begin{abstract}
Higher education is one of the driving forces of the national economy. Educated human capital is important for the development of Latvia's competitiveness. Over the last twenty years, higher education has become an important market service for international markets, as analysed in several studies. In order to ensure the competitiveness of Latvian higher education in Europe, it is necessary to ensure the attractiveness of universities and studies in Latvia not only for local, but also foreign students, new generation teachers, high-level lecturers and guest lecturers. This, in turn, requires the need to improve the quality of studies and living conditions, creation of temporary accommodation for lecturers and guest lecturers, and the provision of jobs promotion of entrepreneurship. The aim of the study is to analyse the trends of higher education development in Riga, and the problems of affordable, high quality housing. The study analyses the dynamics of the number of students in major Latvian universities, the dynamics of the number of foreign students and the current situation in the field of student hotels, has conducted a survey among students on the availability of housing, quality and preferred housing and environment during studies, summarized the results of the survey, and made conclusions and proposals to improve the current situation in student housing. The study also looks at some good examples of student campus development in Latvia as well as the construction of student dormitories abroad, such as modular wooden houses in England.
\end{abstract}

Keywords: competitiveness, development, education, student housing, universities.

\section{Introduction}

As mentioned in the Europe 2020 strategy, adopted by the European Council on 17 June 2010 as the successor to the Lisbon strategy, it is the EU's agenda for growth and jobs for the current decade. It emphasizes smart, sustainable and inclusive growth as a way to overcome the structural weakness in Europe's economy, improve its competitiveness, productivity and underpin a social market economy. There are three mutually reinforcing priorities to make Europe a smarter, more sustainable and more inclusive place to live [1].

The EU's Strategic Framework for Education and Training 2020 (ET2020) aims to foster European co-operation in education and training, providing common strategic objectives for the EU and its Member states for the period up to 2020 Table 1. ET 2020 covers the areas of 1) lifelong learning and mobility, 2) quality and efficiency of education and training, 3) equity, social equity, social cohesion and active citizenship, 4) creativity, innovation and entrepreneurship at all levels of education and training [1].

To support the achievement of these objectives the ET 2020 sets the EU wide benchmarks. In addition to the Europe 2020 targets for smart growth and education [1], other benchmarks are important, such as -1) in average of at least $15 \%$ of adults should participate in lifelong learning, 2) an EU average of at least $20 \%$ of higher education graduates and of at least $6 \%$ of 18 to 34 year olds with an initial vocational qualification should have had some time studying or training abroad, 3) the share of employed graduates (20 to 34 year olds) having left education and training no more than three years before the reference year should be at least $82 \%$ [1-2].

The ET objectives mark out the importance of lifelong studying, mobility and quality of education that should be supported by modern, quality study programs, educated lecturers, as well as motivated students. The EU's strategic objectives in higher education cannot be achieved without the existence of a quality, sustainable learning environment and high quality, modern student housing. The existing student housing problems have become more important in Latvia, especially Riga, by the increasing number of foreigner students and increasing living standards in the EU and the world's most developed countries.

The aim of the research is to analyse the tendencies of higher education development in Latvia and the problems of available, high-quality housing in major Latvian universities. Respondents' survey will find out students' satisfaction with current service hotels, as well as respondents' opinion on the preferred student housing characteristics. 
Europe 2020 strategy key priorities, headline targets and flagship initiatives [2]

\begin{tabular}{|l|l|l|}
\hline \multicolumn{1}{|c|}{ Priorities } & \multicolumn{1}{|c|}{ Targets } & \multicolumn{1}{c|}{ Flagship Initiatives } \\
\hline Smart growth & $\begin{array}{l}\text { Increasing combined public and private } \\
\text { investment in R\&D to 3\% of GDP; } \\
\text { Reducing school drop-out rates to less } \\
\text { than 10\%; } \\
\text { Increasing the share of the population } \\
\text { aged 30-34 having completed tertiary } \\
\text { education to at least 40\%. }\end{array}$ & $\begin{array}{l}\text { Innovation-Innovation Union; } \\
\text { Digital Society - A digital } \\
\text { agenda for Europe; } \\
\text { Education - Youth on the } \\
\text { move. }\end{array}$ \\
\hline $\begin{array}{l}\text { Sustainable } \\
\text { growth }\end{array}$ & $\begin{array}{l}\text { Reducing greenhouse gas emissions by at } \\
\text { least 20\% compared to 1990 levels; } \\
\text { Increasing the share of renewable energy } \\
\text { in final energy consumption to 20\%; } \\
\text { Moving towards a 20\% increase in } \\
\text { energy efficiency. }\end{array}$ & $\begin{array}{l}\text { Climate, Energy and mobility } \\
\text { - Resource efficient Europe; } \\
\text { Competitiveness - An } \\
\text { industrial policy for the } \\
\text { globalization era. }\end{array}$ \\
\hline $\begin{array}{l}\text { Inclusive } \\
\text { growth }\end{array}$ & $\begin{array}{l}\text { Increasing the employment rate of the } \\
\text { population aged 20-64 to at least 75 \%. } \\
\text { Lifting at least 20 million people out of } \\
\text { the risk of poverty and social exclusion. }\end{array}$ & $\begin{array}{l}\text { Employment and skills - An } \\
\text { agenda for new skills and } \\
\text { jobs; } \\
\text { Fighting poverty - European } \\
\text { platform against poverty and } \\
\text { social exclusion. }\end{array}$ \\
\hline
\end{tabular}

\section{Materials and Methods}

Combined research methods have been used in order to obtain correct results for achieving the aims. The following methods have been used - economic analysis, normative document analysis, statistical analysis, logical comparative method; questionnaires and use of personal experience.

The study uses a research method - a survey of students from the largest universities in Latvia. It provides data that are later processed to obtain quantitative information that can be analysed and used to assess the factors influencing student housing development and the selection of critical constraints for further recommendations, as well as to identify the students' desires for quality housing.

\section{Existing situation in Latvia}

Between major cities worldwide there is a growing tendency - competing for educated workforce and diligent students, who are attracted not only by high pay, or highly rated education, but also by attractiveness of the city as well as the country. Riga, the capital of Latvia, is becoming more attractive, it is economically stable and growing, which is most effectively visualized by the GDP.

According to the statistics, there is positive steady economic growth of GDP since 2010 in Latvia. Taking into account the favourable conjuncture - economic growth in the EU and the available EU funds, it is expected that stable economic growth will also prevail in 2019 [3-5].

Although there is steady economic growth in the country, the dynamics of the number of students in Fig. 1 shows non-effective higher education development and modernization, as well as job opportunities and pay after studies. It is equally important for the country's economic growth to hold existing students and graduate students as well as promote export of higher education.

Even though export of higher education is a rapidly growing sector worldwide, no significant increase in public funding for higher education in Latvia is expected in the medium term. Education exports provide additional financial resources for Latvian higher education institutions. The number of foreign students in Latvian universities is growing every year, Fig. 2.

Fig. 2 shows that the number of foreign students could grow dramatically in the coming years. The OECD estimates that the number of people willing to obtain higher education could reach 8 million in ten years. 


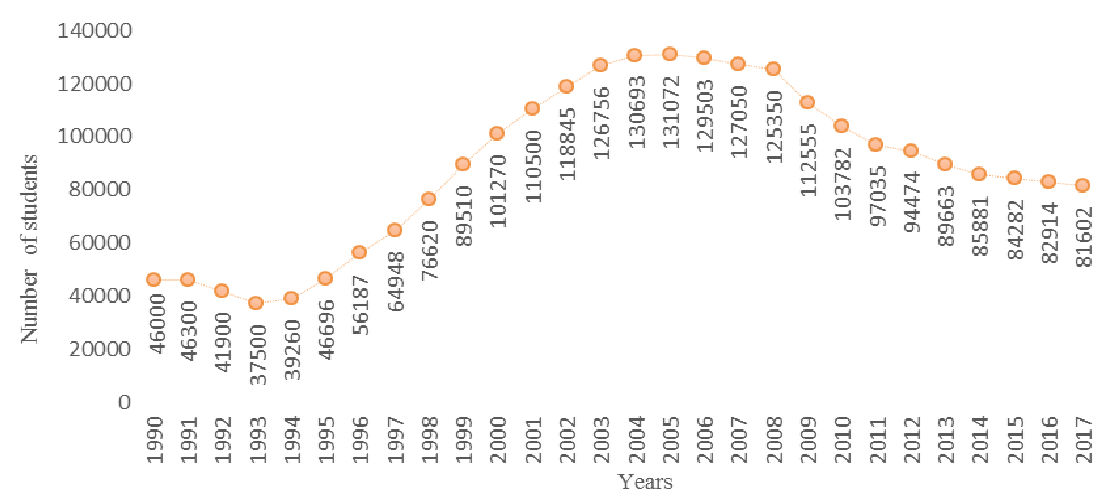

Fig. 1. Dynamics of number of students in Latvia from $1990 / 1991$ to $2017 / 2018$ academic years [6]

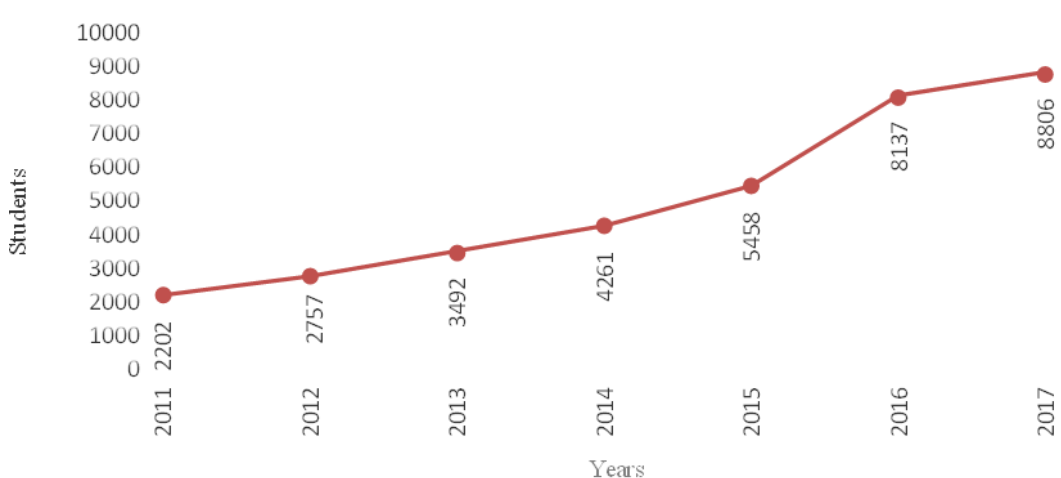

Fig. 2. Changes in number of foreign students in Latvian universities and colleges in 2011-2017 [6]

1Overall, Latvia is an attractive destination for students. Higher education is an industry with significant economic potential that affects the entire economy in Latvia. Higher education is no longer just a consuming industry. In 2016, the Ministry of Education and Science planned budget expenditures for higher education amounted to 63 million euro.

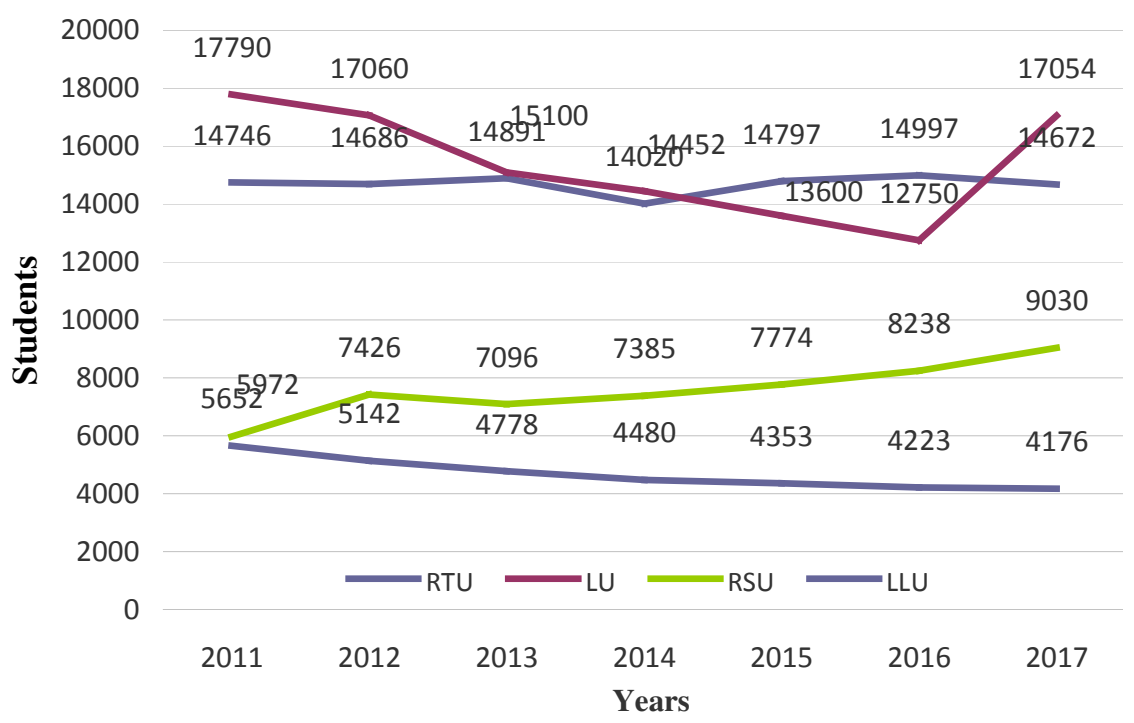

Fig. 3. Dynamics of number of students in largest Latvian universities [6]

Foreign students bring in 28 million euro by study fees alone. Foreign students also partly cover the losses incurred by Latvian higher education due to rapid drop in the number of students in the last decade. In the future, the number of students in Latvia is expected to decrease further, as evidenced by the decreasing number of students in all Latvian universities, shown in Fig. 3. 


\section{Export of higher education and student housing in Latvia}

By development and improvement of quality education programs, educated lecturers and professionals, modern university buildings and modern student housing, it is expected to increase not only education exports, but also to preserve local students in Latvia. One of the significant advantages of university export in Latvia is the development of universities, such as LLU (Latvia University of Life Sciences and Technologies), RTU (Riga Technical University, LU (University of Latvia), RSU (Rīga Stradiņš University) in the city, near the city center. What is not typical for Europe's major capitals is that in the Riga center and in its proximity are large, undeveloped and developing areas with high potential for cooperation between universities, students and professors. Undeveloped areas should be strategically used, by developing not only university buildings, but also student housing, short term flats and university hotels, which are highly requested not only according to the increasing number of foreigner students, but also due to the urban lifestyle and university development in Latvia, especially in Riga, that requires compact city center and compact university development on the left side of the Daugava [7]. The existing situation shows that the price, quality and location of the student housing in major universities in Riga are significantly unequal, Fig. 4.

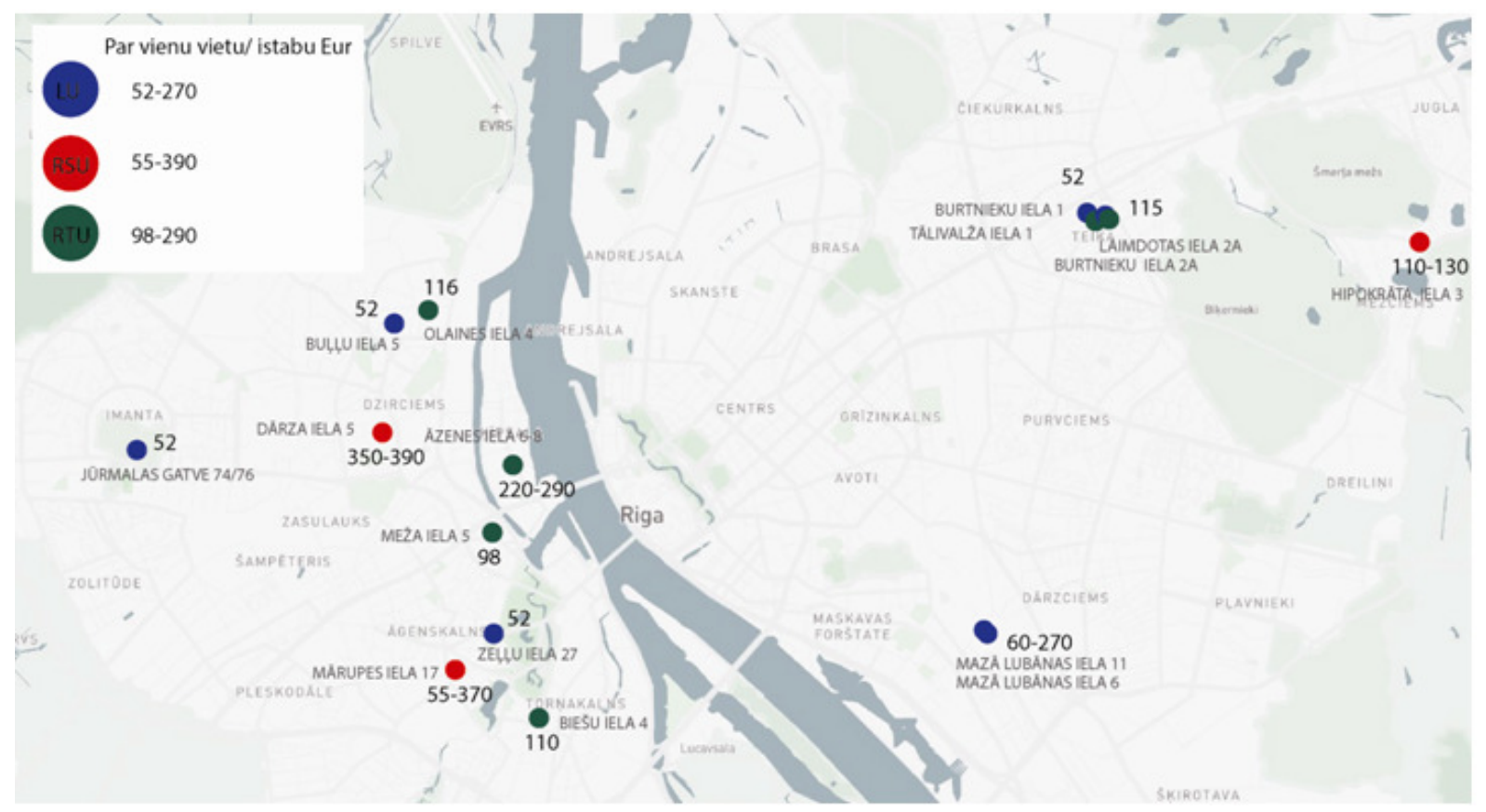

Fig. 4. Student housing of major universities in Riga (The authors' cartography using Mapbox.com)

To find out the current situation in Latvia and public thoughts on the quality of housing of the students in Latvia, questionnaires have been drawn up under the leadership of the authors and a survey has been carried out between the following groups of respondents: LU, RTU, RSU and LLU students. The survey results in completed questionnaires, which have been found to bevel for the processing and analysis of data. The data has been analysed using the "Excel" computer program. The purpose of the sociological research (surveying) - clarifying the situation in Latvia, identifying the existing problems, as well as evaluating the prospects. Taking into account the results of the supply and demand analysis, to find out how to better meet the needs of the respondents mentioned above and to reconcile their interests in student housing.

In order to improve the quality of student housing in Latvia, a research is being conducted on the current and desired situation in hostels in the largest cities of Latvia. The study is carried out at the Faculty of Environmental and Construction Sciences of the Latvia University of Life Sciences and Technologies, Department of Architecture and Construction.

The main questions of the questionnaire were the following.

1. What is your satisfaction with existing university dormitories?

2. Rate of individual indicators in your university dormitories.

3. What do you think would be the ideal dormitory - by the number of students in one room? 
4. Would you like a separate bathroom and kitchen area in the room?

5. Which of these facilities should be in dormitories?

6. The questionnaire survey involved 110 respondents.

\section{Results and discussion} results.

Having conducted the questionnaire and analysed the answers, the authors get the following

The main parameters that describe the quality of the existing student housing are satisfaction of the existing student housing in Latvia and the rate of individual indicators, such as price, location, facilities, modern environment, room climate, sound insulation, quality of bathrooms etc. The surveyed student complaints are mainly about the different quality of the dormitories in Latvia and the prices, which are not always appropriate for the quality. The working environment and quality are improving by building modern university faculties in Riga and other major cities in Latvia.

On the other hand, living environment is not sufficiently consistent with the sustainability principles. The construction of new modern dormitories is highly rated and needed, at the same time more attention should be paid to the left behind, low quality dormitories, Fig. 5.

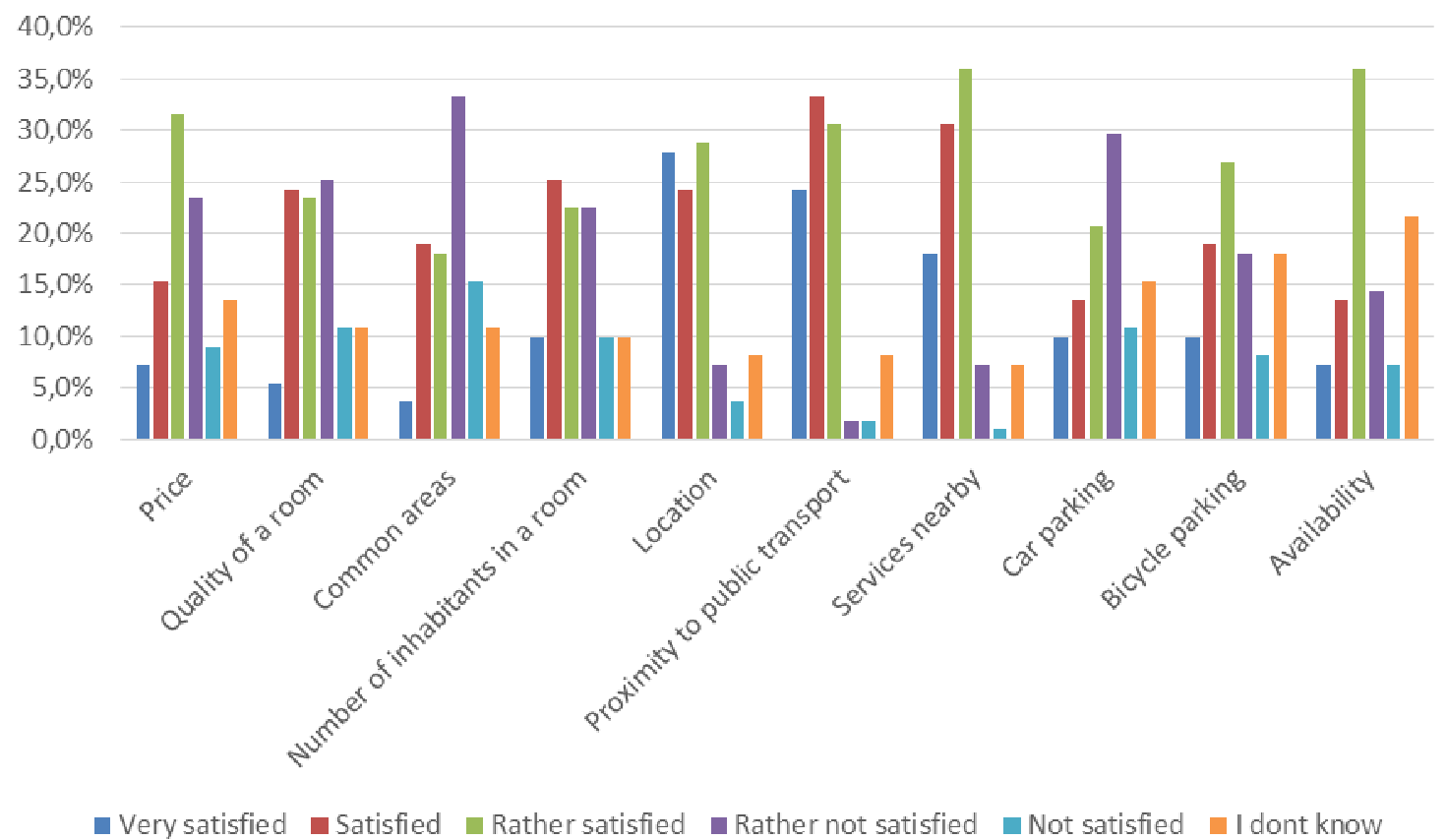

Fig. 5. Satisfaction with existing university dormitories

The main problem relates to the indoor climate, lighting, sound insulation, old equipment and aesthetic environment that need to be adjusted to energy efficient, modern lifestyle. The location of dormitories is being criticized. The time being spent on the road is becoming increasingly important for urban lifestyle, Fig. 6.

The perfect student housing, described by the students, analyses the number of people in the room, facilities needed in the dormitories etc. According to the survey data, $40 \%$ of respondents choose to live in a double room, while $32 \%$ choose to live in a single room, Fig.7.

$35 \%$ of the respondents prefer a separate bathroom and a kitchen area in the room, Fig. 8. According to the survey data, student dormitories should also have sharing spaces, such as a shared lounge (47\%), study room (40\%), games and lounge room (28\%), gym (32\%), Fig. 9.

There is a desire for a variety of prices not according to the quality, but according to the number of students living in a room. Students want apartments and accessible studios, complete with fully fitted kitchens and bathrooms, on a purpose built student centre including a cinema, gym, bars, and restaurants, opening onto a central landscaped courtyard. Students have the desire for larger, brighter rooms with individual desks, shelves and closets for each student Fig. 9. 


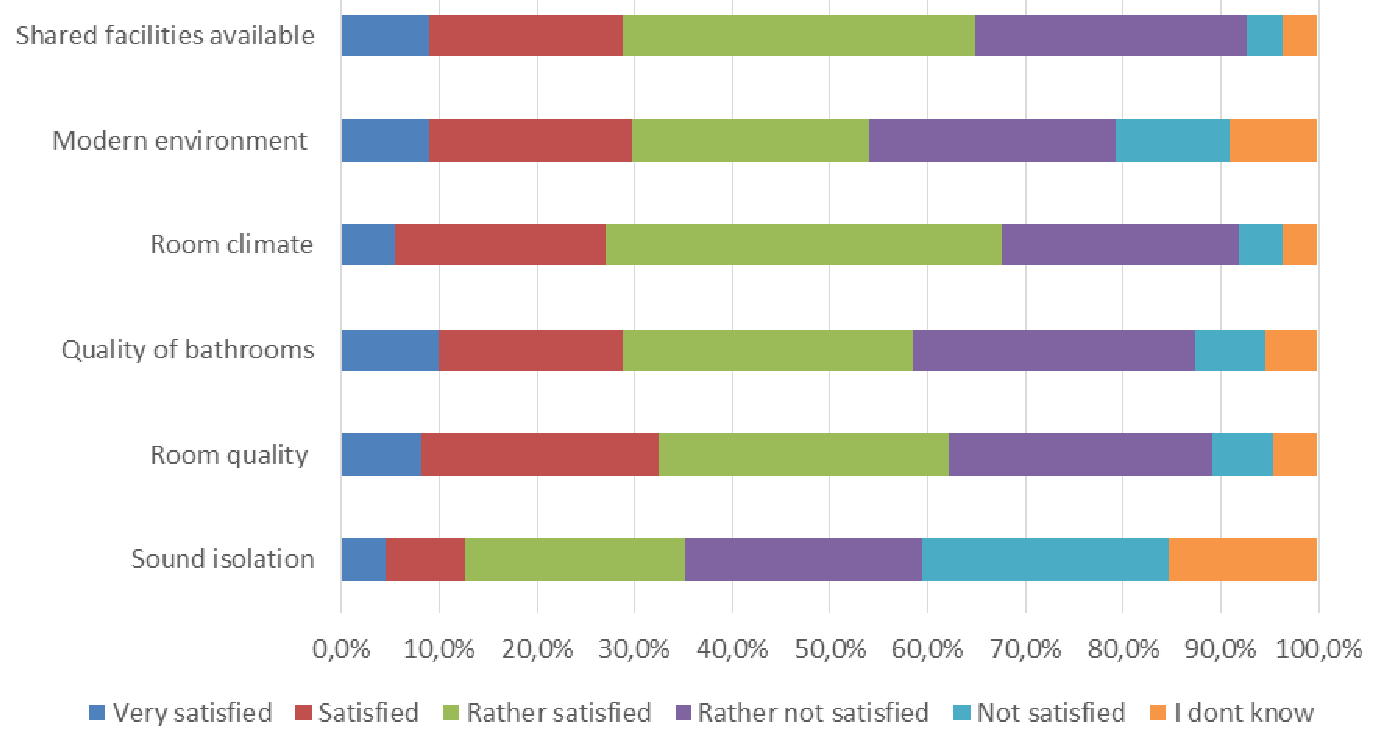

Fig. 6. Rate of individual indicators in your university dormitories

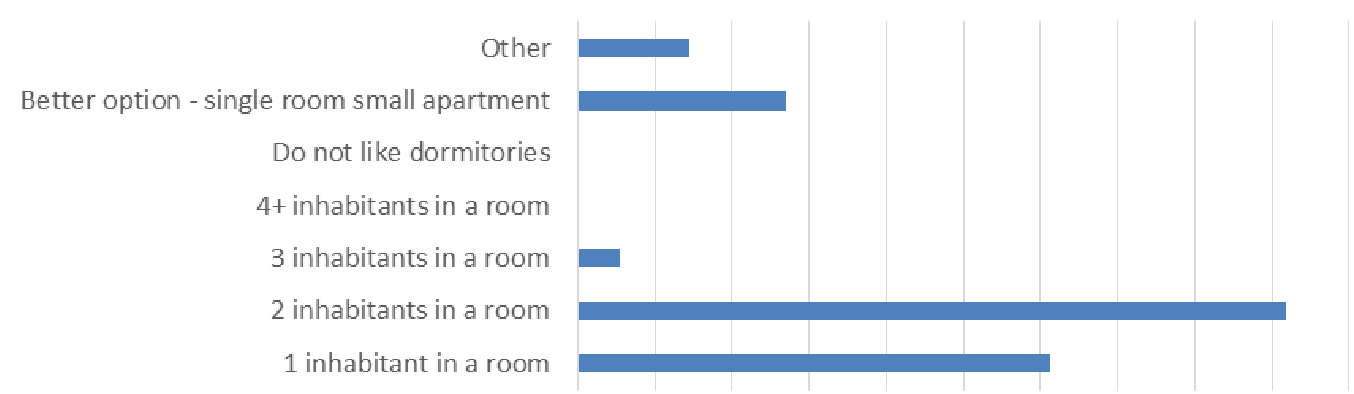

$0,0 \% 5,0 \% 10,0 \% 15,0 \% 20,0 \% 25,0 \% 30,0 \% 35,0 \% 40,0 \% 45,0 \% 50,0 \%$

Fig. 7. What do you think would be the ideal dormitory by the number of students in one room?

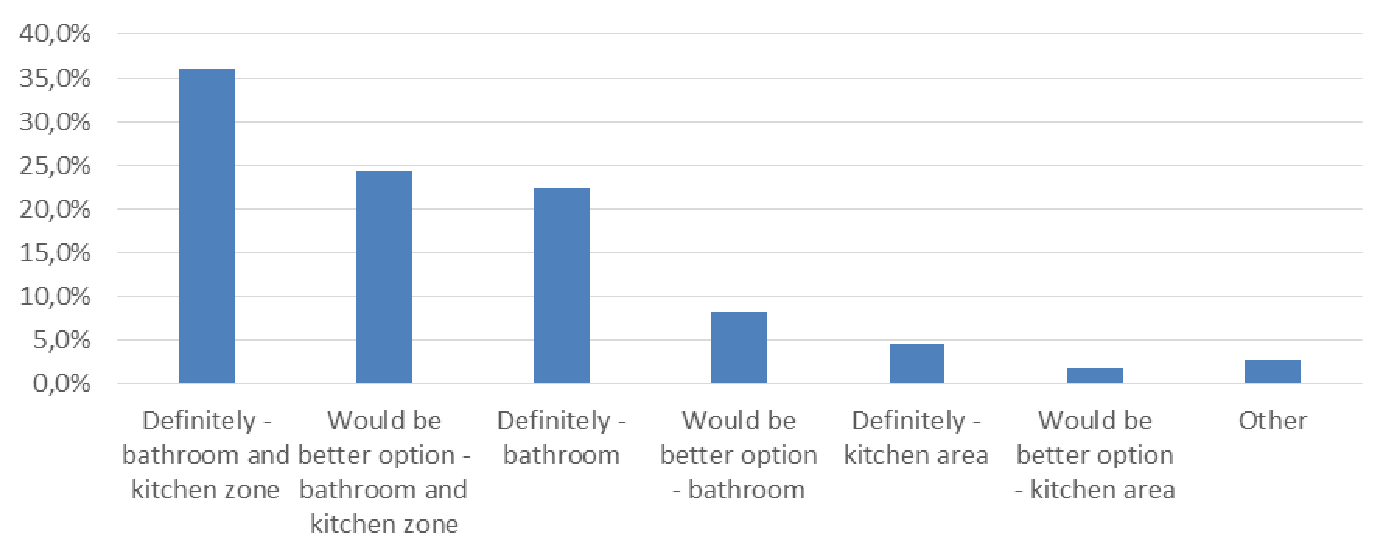

Fig. 8. Would you like a separate bathroom and kitchen area in the room?

According to the location, dormitories up to $15-20 \mathrm{~min}$. walk from the university are being rated highly. 


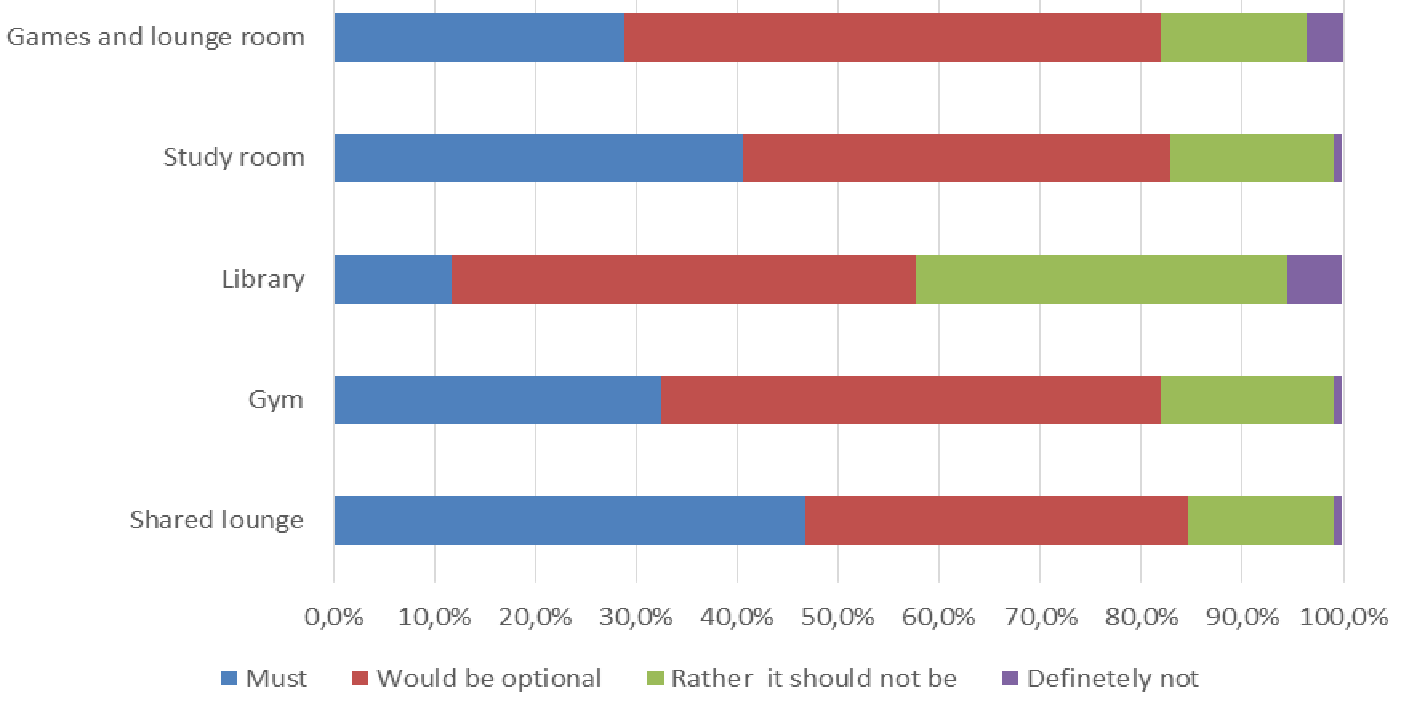

Fig. 9. Which of these facilities should be in dormitories?

\section{Student housing examples in Riga, Denmark and UK}

Analyses of modern, successful student housing projects in Latvia and abroad point out the actual realization of the desired student housing according to the survey. 4 projects were analysed - two in the UK (Liverpool and Plymouth), one in Denmark (Ørestad North), one in Latvia (Riga).

All projects are in a great location -1 to 16 minute walk to the university. Each building has facilities, such as a study room, gym, game room, lounge, secure bike storage. All projects have own bathroom in the room, 3 of 4 projects have a kitchen zone in the room. The project in Ørestad North has a unique solution to promote communication not only indoors, but also outdoors - in a large round courtyard.

According to the sustainable and economic construction in a short term, highly rated is use of modular, as well as partly prefabricated constructions. The main advantage of the offsite construction is reduced construction time and speed of construction that have a huge influence on the building costs [8].

SIA "Nordic Homes", one of the major producers of prefabricated buildings in Latvia, has claimed the advantages of the modular construction [8]:

1. prefabricated buildings are constructed in the factory, according to high quality control and beneficial conditions that has a strong influence on the building quality;

2. production of prefabricated housing units is not affected by the climate conditions and can be provided throughout the year;

3. weather is not influencing materials that results in elimination of inaccuracies in the construction geometry;

4. strength of construction is highly rated due to the previously mentioned advantages;

5. timber frame construction uses certified planed timber with moisture;

6. prefabricated building wood construction is designed according to the Latvian State Standard 184:2000;

7. period of construction is reduced by 30-50\%, compared to on site construction.

According to the above, modular construction is a quick solution in the context of economic growth and availability of European co-financing. Table 2 discusses some of the best examples of student housing. Similar topics are addressed in scientific research by other authors [9-13]. 
Student housing - successful examples [14-18]

\begin{tabular}{|c|c|c|c|}
\hline Object & Location & Construction description & $\begin{array}{l}\text { Location } \\
\text { description }\end{array}$ \\
\hline $\begin{array}{l}\text { St. Augustine's house / } \\
\text { Nordic Homes }\end{array}$ & Plymouth, UK & \multirow{2}{*}{$\begin{array}{l}\text { - } 6 \text { storey building; } \\
\text { - } 89 \text { students apartments; } \\
\text { - } 95 \text { modules; } \\
\text { - GLA - } 2600 \mathrm{~m}^{2} ; \\
\text { - Completion - } 2013 ; \\
\text { - Each room - own } \\
\text { bathroom, kitchen zone; } \\
\text { - Gaming room, study zone, } \\
\text { 1 lounge, private gym and } \\
\text { secure bike storage - free. }\end{array}$} & \multirow{2}{*}{$\begin{array}{l}\text { - } 16 \text { min. walk } \\
\text { to university; } \\
\text { - } 20 \text { min. walk } \\
\text { to central } \\
\text { station. }\end{array}$} \\
\hline $\begin{array}{l}\text { (Author-unknown) } \\
\text { [14-15] }\end{array}$ & $\begin{array}{l}\text { (the authors' } \\
\text { cartography, using } \\
\text { Google Maps) }\end{array}$ & & \\
\hline $\begin{array}{l}\text { Hope St - Liverpool / } \\
\text { NORDIC HOMES }\end{array}$ & Liverpool, UK & \multirow{2}{*}{$\begin{array}{l}\text { - } 3 \text { towers: 5,7,9 storeys; } \\
\text { - } 339 \text { students apartments; } \\
\text { - } 309 \text { modules; } \\
\text { - GLA - } 7515 \mathrm{~m}^{2} \text {; } \\
\text { - Completion - 2015. } \\
\text { - Each room - own } \\
\text { bathroom, kitchen zone; } \\
\text { in-house cinema, study } \\
\text { room, gym, game room. }\end{array}$} & \multirow{2}{*}{$\begin{array}{l}-8 \text { min. walk to } \\
\text { university; } \\
-11 \text { min. walk to } \\
\text { central station. }\end{array}$} \\
\hline 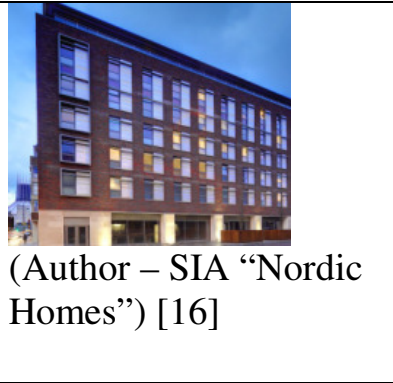 & $\begin{array}{l}\text { and } \\
\text { and } \\
\text { (the authors' } \\
\text { cartography, using } \\
\text { Google Maps) }\end{array}$ & & \\
\hline $\begin{array}{l}\text { Tietgen Dormitory / } \\
\text { Lundgaard \& Tranberg } \\
\text { Architects [17] }\end{array}$ & $\begin{array}{l}\text { Near Copenhagen } \\
\text { University in Ørestad } \\
\text { North. Denmark }\end{array}$ & \multirow{2}{*}{$\begin{array}{l}\text { - } 400 \text { students ; } \\
\text { - Partly prefabricated; } \\
\text { - 7-storey building; } \\
\text { - Completion - } 2005 ; \\
\text { - Shared space in the centre; } \\
\text { - In the floor } 12 \text { residences, } \\
\text { around a communal area and } \\
\text { kitchen; } \\
\text { - Each room - own } \\
\text { bathroom. }\end{array}$} & \multirow{2}{*}{$\begin{array}{l}-1 \text { min. walk to } \\
\text { university; } \\
-14 \text { min. bike } \\
\text { ride to central } \\
\text { station; } \\
-20 \text { min. public } \\
\text { transport to } \\
\text { central station. }\end{array}$} \\
\hline $\begin{array}{l}\text { (Author-Jens M. } \\
\text { Lindhe) [17] }\end{array}$ & $\begin{array}{l}\text { (Is) } \\
\text { s } \\
\text { (the authors' } \\
\text { cartography, using } \\
\text { Google Maps) }\end{array}$ & & \\
\hline $\begin{array}{l}\text { RSU Student Hostel / } \\
\text { SIA "Nams" }\end{array}$ & $\begin{array}{l}\text { Dzirciems, Darza } \\
\text { street, Riga, Latvia }\end{array}$ & \multirow{2}{*}{$\begin{array}{l}\text { - 220 students; } \\
\text { - Built on site; } \\
\text { - 3-storey } \\
\text { building + basement; } \\
\text { - Completion - 2017; } \\
\text { - Multi room apartments, } \\
\text { separate rooms with } \\
\text { amenities, kitchen; } \\
\text { - Bicycle, car parking } \\
\text { underground; } \\
\text { - Gym, study room, } \\
\text { communal area, game room. }\end{array}$} & \multirow[t]{2}{*}{$\begin{array}{l}\text { - } 2 \text { min. walk to } \\
\text { university; } \\
\text { - } 26 \text { min. public } \\
\text { transport ride to } \\
\text { central station; } \\
\text { - } 3 \text { min. walk to } \\
\text { public transport. }\end{array}$} \\
\hline (Author-Unknown) [18] & $\begin{array}{l}\text { authors } \\
\text { (the authors' } \\
\text { cartography, using } \\
\text { Google Maps) }\end{array}$ & & \\
\hline
\end{tabular}




\section{Conclusions}

1. Export of higher education is a rapidly growing sector of Latvian economic services. Education export provides additional financial resources to higher education institutions in Latvia. Foreign students in Latvia also promote modernization of higher education programs, professors and administration, as well as development of modern student housing from which all students can benefit.

2. The results of the research show that there is a lack of a common strategy for improving student housing in terms of improving housing and living environment, as well as a lack of organized activities in the field in individual universities.

3. The main problem of student housing relates to the indoor climate, lighting, sound insulation, old equipment and aesthetic environment that need to be adjusted to energy efficient, modern lifestyle. Students have the desire for larger, brighter rooms with individual desks, shelves and closets for each student.

4. The major advantage of the offsite construction is reduced construction time and speed of construction that has a huge influence on the building costs.

5. Using of modular construction in high-quality student housing is one of the quick solutions in the context of economic growth and availability of European co-financing.

\section{References}

[1] Smarter, greener, more inclusive? INDICATORS TO SUPPORT THE EUROPE 2020 STRATEGY 2 [online] [15.03.2019]. Available at: https://ec.europa.eu/eurostat/documents/3217494/7566774/KS-EZ-16-001-EN-N.pdf

[2] Council conclusions of 12 May 2009 on a strategic framework for European cooperation in education and training ('ET 2020'). Official Journal of the European Union [online]. [15.03.2019]. Available at: https://eurlex.europa.eu/LexUriServ/LexUriServ.do?uri=COM:2010:2020:FIN:EN:PDF

[3] Šogad trīs ceturkšņos sasniegta straujākā enomikas izaugsme pēdējos gados (This year's fastest economic growth in the three quarters of recent years). (In Latvian). [online]. [15.03.2019]. Available at: https://em.gov.lv/files/attachments/LV_GDP_2018_Q_3.pdf

[4] Latvijas ekonomikas attīstības pārskats (Economic Development Review of Latvia). [online]. [15.03.2019]. Available https://www.em.gov.lv/files/tautsaimniecibas_attistiba/leap/leap_2018.pdf (In Latvian).

[5] Gusta S. Sustainable construction in Latvia - opportunities and challenges / Sandra Gusta // 15th International scientific conference "Engineering for rural development": proceedings, Jelgava, Latvia, May 25-27, 2016 [elektroniskais resurss] / Latvia University of Agriculture. Faculty of Engineering. Jelgava, 2016. Vol.15, pp. 1291-1299.

[6] (Overview of Higher Education in Latvia 2017. Higher Education, Science and Innovation Department). [online] [15.03.2019]. Available at: https://www.izm.gov.lv/images/statistika/augst_izgl/AII_2017_parskats.pdf (In Latvian)

[7] Auers D., Dubins S. Augstākās izglīitības eksporta ekonomiskā nozīme un ietekme Latvijā. Politikas pārskats \# 1 (Economic significance and impact of higher education exports in Latvia. Political Revew \#1). Riga: Domnīca Certus. 2016. (In Latvian). ISBN 978-9934-8558-4-9

[8] Student Accommodation (In English). [online]. [15.03.2019]. Available at http://nordichomes.lv/en/nhproducts/student-accommodation

[9] Bindemane H.L. Development of student residences in a contemporary context BACHELOR THESIS 2019, RISEBA

[10] Boafo F.E., Kim J.-H., Kim J.-T. Performance of modular prefabricated architecture: Case studybased review and future pathways (Open Access) (2016) Sustainability (Switzerland), 8 (6), art. no. 558. [online] [25.03.2019]. Available at: http://www.mdpi.com/2071-1050/8/6/558/pdf doi: $10.3390 / \mathrm{su} 8060558$

[11]Lee J.-H., Kim J.-S., Lee H.-J., Lee Y.-M., Kim H.-G. Small-scale public rental housing development using modular construction-Lessons learned from case studies in Seoul, Korea (2019) Sustainability (Switzerland), 11 (4), art. No. 1120. 
[12] Moore H.P., Carswell A.T., Worthy S., Nielsen R. Residential Satisfaction among College Students: Examining High-End Amenity Student Housing (2019) Family and Consumer Sciences Research Journal, 47 (3), pp. 260-275.

[13] Khozaei F., Hassan, A.S., Al Kodmany K., Arab Y. Examination of student housing preferences, their similarities and differences (2014) Facilities, 32, pp. 709-722

[14] About St Augustine's house - Plymouth. [online] [29.03.2019]. Available at: https://www.crmstudents.com/student-accommodation/plymouth/st-augustines-house/

[15] Plymouth [online] [25.03.2019]. Available at: http://nordichomes.lv/en/produkti/plymouth/

[16]Liverpool [online] [25.03.2019]. Available at: http://nordichomes.lv/lv/produkti/liverpule/

[17] Tietgen Dormitory / Lundgaard \& Tramberg Architects. (In English) [online] [25.03.2019]. Available at: https://www.archdaily.com/474237/tietgen-dormitory-lundgaard-and-tranbergarchitects

[18] RSU student hostel Dzirciems. [online] [25.03.2019]. Available at: https://www.rsu.lv/en/studenthostel-dzirciems 